p.92

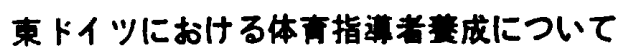

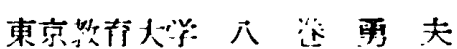

\section{一 はじめに}

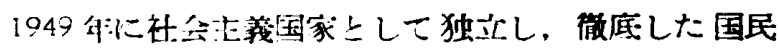
数志を行なつている東ドイッの体青を概観し，その指道

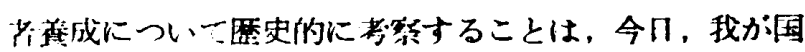

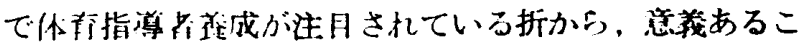
とたと思う。

\section{二 社会体奇指咅者誉成について}

活ドイソの六ポーツ活勘の初期には，特に大䌽スボー

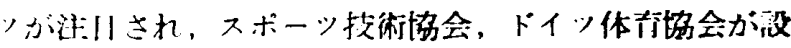

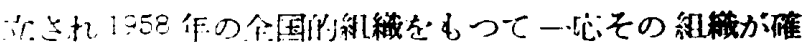

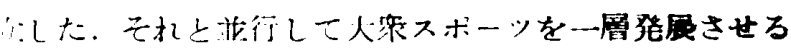

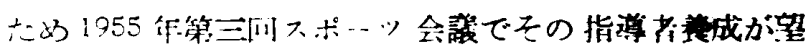
まれ，行遇動指槊員，トレーナ一，行地城各地区及びス

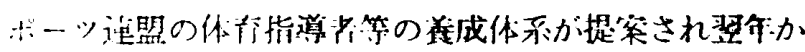

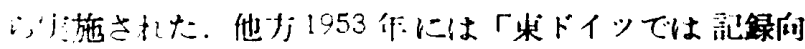

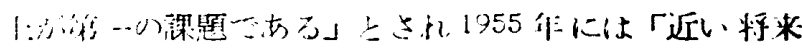

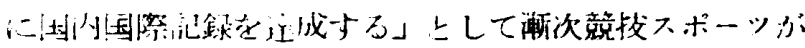

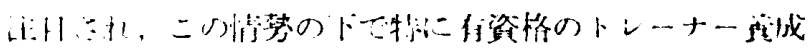

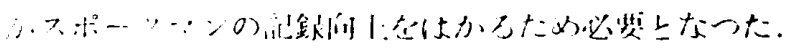

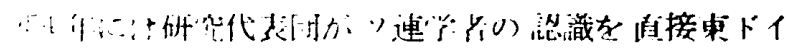

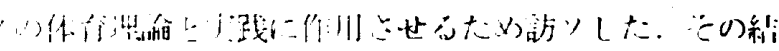

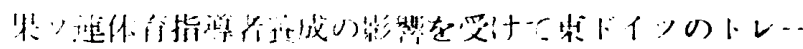

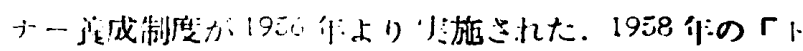

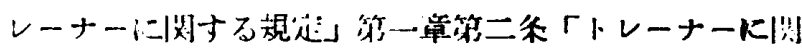

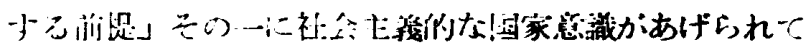

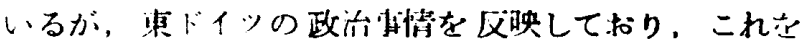
1958 作9月に始まるドイッ体有大学の通信教育教长型 ロにみると，社会主義的意職形成の手段として，又，各 学到の根底をなおすのとして，社会科学の中で，特质 証法的史的倠物論が重視されている，曹門領城では，そ の理斒と䒠践にすぐれた知識が得られるよ5政さされて

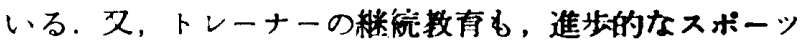

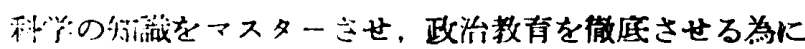
必是と㣽机ている。

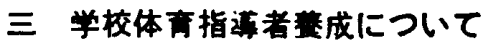

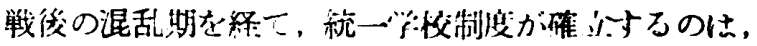

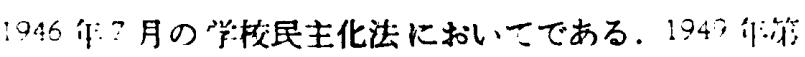
忺间教育会議では，教育と学校の統一を你心るために，

政活们禹門的に高度の资質をるつた教育が望まれ，1952 年のドイッ共座党中央委員会では「ドイッ民主主我学校 は曼国者を苔成する任務を有する」として学校の課題を

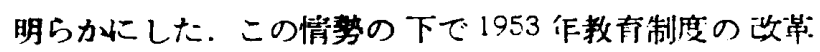

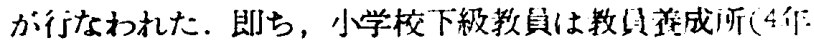
制) 同、級休青教員はハレ 教育専門学校（2 年制）高等 学校体育教買はトイッ体育大学及び各総合大学 (4 年制) で成され，その後国家試験を程て瓷格を得た。1958 作第五的党大会では，「反フフシズム，民主々義似”兴校

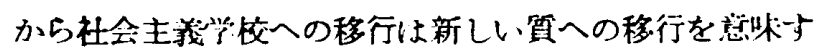
る」として，学校制度が改められてた，更に「学校制度を 一局発展させるにあたつて核上なるべき問影は総合技術

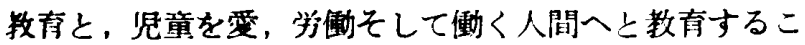

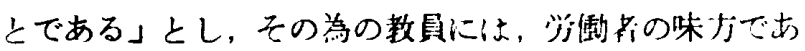

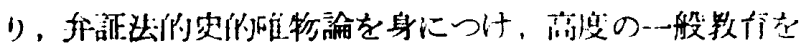

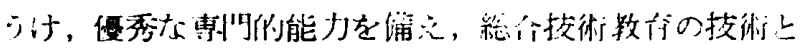

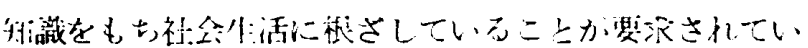

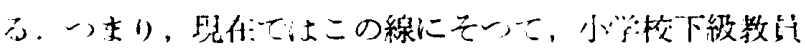

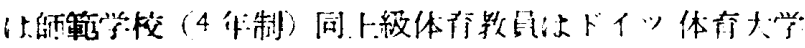

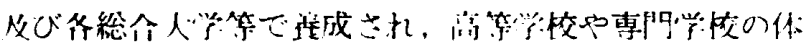

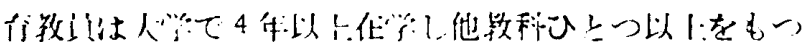

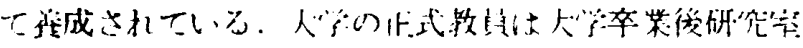

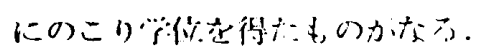

\section{四まとめ}

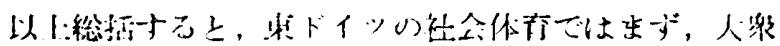

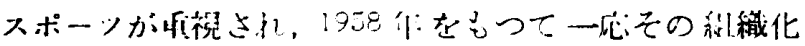

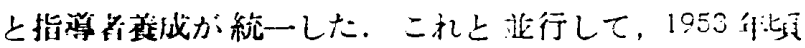
から徐々に競技スポーツが記録向上による政治似果題の 解消という形で注日され，その為特:にトレーナー一永成が 1958 作を中心として確守していく，他方，少校体予指

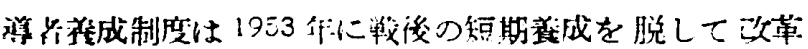
され，更に1958作には，学校の質似転換に伴つて业び 较められ，強化されて今日に至る。その内容についてみ ると，徽底した政治教育の下で，社会主義的体育指導考

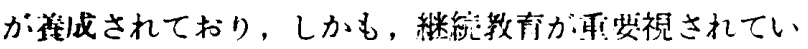
る点に泣月したい。 